\title{
Yuval Levavi. "A peculiar taxation practice of Judean exiles in rural Babylonia and its possible connection to building activity in late sixth century Judah"
}

\section{Reinhard Pirngruber}

\section{(2) OpenEdition}

\section{Journals}

Electronic version

URL: https://journals.openedition.org/abstractairanica/51757

DOI: 10.4000/abstractairanica.51757

ISSN: 1961-960X

Publisher:

CNRS (UMR 7528 Mondes iraniens et indiens), Éditions de l'IFRI

Electronic reference

Reinhard Pirngruber, "Yuval Levavi. "A peculiar taxation practice of Judean exiles in rural Babylonia and its possible connection to building activity in late sixth century Judah"', Abstracta Iranica [Online],

Volume 42-43 | 2021, document 8, Online since 30 December 2020, connection on 28 December 2022 URL: http://journals.openedition.org/abstractairanica/51757 ; DOI: https://doi.org/10.4000/ abstractairanica. 51757

This text was automatically generated on 28 December 2022.

All rights reserved 


\title{
Yuval Levavi. "A peculiar taxation practice of Judean exiles in rural Babylonia and its possible connection to building activity in late sixth century Judah"
}

\author{
Reinhard Pirngruber
}

\section{REFERENCES}

Yuval Levavi. "A peculiar taxation practice of Judean exiles in rural Babylonia and its possible connection to building activity in late sixth century Judah" in A. Berlejung, A. M. Maeir (eds.). Research on Israel and Aram: Autonomy, Interdependence and Related Issues. Proceedings of the First Annual RIAB Center Conference, Leipzig, June 2016. (RIAB, Vol. 1), Tübingen: Mohr Siebeck, 2019, p. 395-407

1 On the basis of a new reading of a hitherto misconstrued passage found in some legal records belonging to the so-called Āl-Yahūdu texts, this contribution argues that construction works undertaken in the province of Judah in the reign of Darius were partly financed by levies imposed on Judean deportees in rural central Babylonia (near Nippur). Specifically, the deportees mentioned in the pertinent texts belonged to the class of šušānus, semi-dependent worker on government holdings, who were under the authority of governor Uštana and whose imposts were assigned to the the province of Across-the-River (Syria and the Levant). The author is thereby able to elucidate a passage in the book of Ezra (1:4) hinting at such an arrangement. 


\section{AUTHORS}

\section{REINHARD PIRNGRUBER}

Institut für Orientalistik, Wien 